\title{
Founderitis: A Silent Killer of Startups
}

\author{
Chuck Sacco (Drexel University) \\ Aasim Sani (Drexel University)
}

KEYWORDS: Leadership, Startups, Team Development.

It is well-known that only a small fraction of startups achieve long-lasting success. They often fail not because their idea is poor but because of problems executing on their idea. One area that is often problematic for startups is how the startup team develops and operates. In fact, it is common for a team with a very viable idea to self-destruct because they ignored team challenges or could not figure out how to work well together (Janz 2014).

Sometimes, a founder's issues undermine even teams with top-notch talent. This situation, called "founderitis,"1 occurs when one of the founders wields disproportionate power and influence. The result is a wide range of problems for the organization including poor strategic planning, inability to take sufficient input from others inside and outside the company, and undisciplined decision making.

For a case study in founderitis, consider NegotiationAl, an early-stage company that has developed a platform allowing users to evaluate and improve their negotiation skills by leveraging artificial intelligence (Al). The platform helps train people efficiently by delivering objective "hard" technical analysis of the soft-skill of person-to-person negotiation.

The case provides a history of the first 18 months of the company, revealing the organizational design and structures they developed, the progress made, the challenges they encountered and how they managed to move forward. We discuss how the founders defined their roles, organized hierarchies, set goals, made decisions, executed plans and where they struggled at each stage. This case also shows the dichotomy of external perception (high flying, early success, press, awards, competitions) with the internal conflicts at each phase.

This case was developed with the direct input of a key team member (originally with non-founder status but

who was later granted founder status) who assisted by performing team interviews, reviewing team history, and analyzing the team's outcomes. The company name, products, and team member names have been changed to protect their identities.

Note to teachers: Download teaching notes for this article by clicking the above link.

\section{Founding: The Initial Idea Progress}

NegotiationAl was conceived at a hackathon in May 2016, as a virtual reality (VR) product idea that the team of Don Carey, Evan Paulson, Justin Marks and Caleb Smith created when they were thinking about how they could improve their negotiation skills (virtual reality is a computer-generated simulation of a multi-dimensional environment where individuals can interact with that environment using equipment such as headsets, gloves, and other devices). The platform was developed in VR because Justin had basic technical expertise in VR and because they thought it would be fun to try to build something in a brand-new technology. As a group of talented young university engineering and computer science students, their efforts got them into the top 10 finalists at the hackathon.

After the hackathon, only Justin and Caleb decided to pursue the idea. The others decided not to move forward due to coursework and work demands. Justin and Caleb, while they communicated regularly, initially worked on the idea separately, each taking a different approach. Caleb was trying to validate the market opportunity as a personal-use product (using design mock-ups to get feedback) while Justin was working to learn more about the basics of VR technology.

In September of 2016, Caleb and Justin met on campus to compare their efforts to-date and decided to start pursuing the idea seriously and to do it together. Their 
initial market ideas were not particularly well-defined as they were simply pursuing this idea as young entrepreneurs who thought they could make something "cool." Without a well-defined market focus, they decided to create the application for anyone who might need to improve their negotiation skills and with this came their first prototype.

As with many early-stage technologies, they faced significant technical issues with this first version as it was not very stable and did not have the best user experience. It did, fortunately, convey their basic value proposition by showing users how to interact in a basic salary negotiation setting. Donning a VR headset, a user could "see" themselves in a salary negotiation setting, while the technology analyzed their speech patterns and recommended certain statements that could be made to negotiate a better salary.

The team decided to incorporate as an LLC and raised $\$ 20,000$ from friends and family to help kick-start the idea.

\section{Team structure and decision making}

The team decision-making was very democratic at this founding stage. Caleb and Justin made decisions about where to steer the company and then leveraged parttime developers and other freelancers to get much of the core work accomplished. As with many studentbased startups, their commitments could only be parttime as Caleb and Justin both were focused on their schoolwork. Additionally, Caleb was working as the head engineer for another startup up on campus, though he eventually abandoned those efforts to commit fully to NegotiationAl.

\section{Team challenges and risk}

A major source of concern at this point was that the core team had not yet organized their activities, nor had they documented their workflow and process very well. They were disorganized and they had serious issues with communicating progress, especially since they were working on it part-time and often not at the same time of day.

Compounding those issues, Caleb believed that the product was not getting built quickly enough while Justin knew he needed to focus on learning a highly-advanced technology and get early versions of the product out for testing. Progress was slow. Caleb, who lacked technical skills, became frustrated when Justin explained to him that his ideas weren't technically feasible or that he didn't have time to execute them because of school work and other commitments.

The team was encountering major operational and management risk, though everything still seemed exciting and worth pursuing. This led to decisions such as participating in major hackathon competitions to raise more money. With their exciting "cool" idea very appealing to hackathon participants and judges, they continued to place very well and bring more cash into their nascent business. Life seemed good and everything seemed possible.

\section{Phase 1: Major Pivot and Winning an Entrepreneurship Competition Progress}

In November 2016, based on feedback they were getting on the idea after participating in university-based entrepreneurship mentoring programs, the team decided to change their market focus away from a general-purpose application for anyone and towards a potentially larger B2B market opportunity focused on sales representatives in companies who needed help in developing their negotiation skills. This approach also meant that they would need to abandon VR, as enterprise-level adoption of that modern technology was very risky. Instead, they decided to focus on developing the negotiation skills technology as a mobile application with a heavy emphasis on the use of artificial intelligence (Al) technologies (artificial intelligence technologies are computer systems that can perform tasks normally delivered by humans, using large datasets and advanced computing to simulate human efforts).

Significant validation at this point came when the team won a major university-based business plan competition and placed very highly in several other startup competitions. This helped convince the team that their idea was worth pursuing and provided them with the validation they needed to get themselves and others more on-board with the idea. They decided to find people for the project and build a more capable team (primarily on the technical production side of the operation). The team moved into their university's incubator which provided entrepreneurial skill development and mentoring to help them advance their idea more effectively and efficiently. 
Because of these efforts, the first iteration of the enterprise-version of the mobile application product was launched in March 2017. The team still saw it as a prototype in quality level, but Caleb was convinced it was good enough for widespread adoption and was under the (eventually false) assumption that it would become viral immediately.

Near the end of the Summer of 2017, the company was unable to deliver the right product because of continued disconnects in communication and frustrations faced by the team as well early indications of founderitis, meaning that Caleb had disproportionate power and influence, leading to a wide range of problems for the organization. Caleb also didn't leverage the incubator resources available to the team, believing that he had everything under control. He believed there was no need to risk the incubator resources available to the team by bringing up any "bad news."

\section{Team structure and decision making}

Over the next few months, the balance of power shifted significantly as Caleb positioned himself as the company CEO and focused on going out to regional entrepreneurship events to get product feedback. Unfortunately, because he didn't understand how to validate new startup ideas effectively, he was not truly validating the product with this approach. Instead, he was simply showcasing it to people who likely were not NegotiationAl's customers. Likewise, at this point, Justin had not developed the skills to be a good technical manager and was buried too deeply within the product development to focus on strategic issues.

\section{Team challenges and risk}

As first-time founders with no management experience, Caleb and Justin were going primarily on instinct. Caleb seemed to be developing into more of the "hustler" role, while Justin was taking on the "hacker" role.

As the team moved towards deploying their new application and market approach, Caleb thought that many companies would adopt their technology and that they would become an overnight success. Justin, on the other hand, was much more skeptical but was following Caleb's lead at this point without much validation or challenging of assumptions.

During this time, Caleb also began to think of Justin as a replaceable asset, leading to an extremely uncomfortable conversation. Caleb brought Justin into a meeting where he laid out to him a roadmap of NegotiationAl's progress and claimed success for all of it, meaning that Justin was replaceable. Caleb also stated that he should get more equity and power to more efficiently make decisions for the company. This led to a period when the company had no clear direction and became significantly stagnant, as Justin was not motivated to continue leading the technology development.

The pivot from a consumer-facing company to a B2B company also illustrates a typical challenge of many early-stage startups: they are an idea in search of a market. Once they realized that grabbing consumer attention was going to be more difficult than they ever imagined, the team needed to figure out the market opportunity (assuming a viable one could be had).

It was a very risky time for NegotiationAl.

\section{Phase 2: New Market Approach Progress}

Finding that they were unable to achieve market validation as quickly as they thought, and considering that they might be pursuing an idea whose technical feasibility was questionable for their intended market, the founders decided to pursue a different strategy by focusing on custom solutions for selected organizations. This would allow them to work closely with potential customers and ensure they were building the right product for the right users and purpose.

Fortunately, during the prior months, they had developed a strong relationship with a large communications company and worked with them to develop an updated version of their application that offered the ability to serve negotiation lessons to sales representatives within the application. This was a significant pilot project opportunity for the team and helped them raise an additional $\$ 30 \mathrm{~K}$ from competitions with $\$ 100 \mathrm{~K}$ of in-kind services, which allowed them to pursue their new product and market development strategies.

The team continued to incubate in their university's incubator, but they rarely attended entrepreneurship workshops and didn't actively seek out advice from the mentoring teams available to them. They were smart students and they believed they could more or less go it alone. Plus, they were so busy with their work and school efforts and believed they didn't have much time 
for others outside their core new venture activities.

\section{Team structure and decision making}

Through this phase of the startup, the company's team fluctuated and changed significantly, with Caleb and Justin retaining the positions as CEO and CTO respectively. They resolved some of their earlier equity allocation conflicts and decided to move ahead despite the product, market and team challenges. They added five team members including a COO, VP of Marketing and three respected industry advisors (who may have been there in name only as they seemed to have little influence on the operation). However, two of their senior team members left suddenly because of other obligations. At this point, the team seemed in great turmoil with all these additions and departures. While they added interns to assist, the team struggled with their effectiveness.

\section{Team challenges and risk}

The decision-making structure had become increasingly hierarchical over the course of the year, and this caused NegotiationAl to make mistakes and fall short in verifying and validating some ideas. The rapid fluctuations in the team, while not apparent to Caleb and Justin, showed that they had a disconnect in either their ability to evaluate candidates or their expectations of the candidates.

During this stage of the startup, they encountered significant team risks because of the quick changes in the team as well as Caleb's increasing founderitis. Caleb's dictatorial management style led to many issues with open communication within the company, including team members talking behind Caleb's back. This was a symptom of Caleb's frustration with the product's slow progress and his poor understanding of how technology development cycles work. Justin's inexperience with leading technical teams added to the challenging situation.

Another major factor was their assumption that the interns they hired would be able to produce an industrylevel product. Beyond this, the team kept repeating mistakes because they never kept records of past mistakes or whether a certain process was working.

Finally, the team made a classic startup mistake by hiring a "VP of Sales" when the startup was still working to determine its "product-market fit" -- the match between the product they created and the market that needs or wants the product. The VP was in a no-win situation because the company had nothing to sell, despite Caleb's belief they had a solid product ready to take on the market.

\section{Phase 3: A New Iteration Progress}

Despite the major changes in the team dynamics and the challenges caused by Caleb's founderitis, the team somehow managed to pull their work together over the coming months and launch NegotiationAl's next iteration during the pilot with the communication company. With this one pilot project underway, NegotiationAl decided to focus its market development efforts to find similar companies with large sales teams that needed negotiation skill improvement. However, the application had serious issues and the development done by the outsourced developers was not suitable for use in large organizations. The company launched this next iteration in November 2017 and they raised an additional $\$ 45,000$ from competitions.

The team also added a new Product Manager (Kevin), a university entrepreneurship student, who brought to the table a unique mix of technical and entrepreneurial skills. Kevin took on the role as the team's "hipster" and was able to see some of the team's key management challenges. Kevin pushed Caleb and Justin to become better informed on how to build their startup team, how to organize themselves and how to validate a new venture opportunity.

As a result, the team was able to produce three pieces of defensible intellectual property and secured its first enterprise client. They also learned during this time that big corporations were not as much of an under-served market as they anticipated and decided to switch to a market focus of small and medium-sized businesses (SMBs) which seemed more accessible and would tolerate an imperfect product.

\section{Team structure and decision making}

Recognizing that the company was at risk because it wasn't producing a stable product, the company worked to create a formalized procedure for testing and developing features using advanced analytics tools. The goal was to increase transparency, to empower employees and to create an environment more open to innovating and being able to find mistakes faster. With the introduction of the new structuring, a culture of accountability was created where everyone was 
answerable to everyone and therefore semidemocratized. The dynamic enabled more open communication among employees while improving the issues that existed because of founderitis.

\section{Team challenges and risk}

The team struggled to get better developers during this period. However, this gave the team room to carve out a new trajectory for the product. They realized the development team should focus on a superior end-user experience while the management team worked to develop the market opportunity through industry partners.

The major conflicts that existed during this phase were associated with the difference in communication styles between the new Product Manager, Kevin, and CEO Caleb. Kevin had an aggressive communication style that was in turn aggravated by Caleb's communication style. Neither could effectively convey their ideas to each other; Caleb could not express his doubts clearly and Kevin perceived this as Caleb's ignorance of ideas and suggestions.

\section{Current Status and Final Notes}

Despite their challenges, the company was accepted into a major technology accelerator program and was able to raise a significant round of investor capital, while continuing to grow and develop the team. The accelerator program pushed the team to improve the product quality and usability, which will be necessary for adoption within the SMB market. With the pivots and team development efforts, the company may be able to find its product-market fit and operate exceptionally without running out of funds. The story is not yet complete, but despite challenges the NegotiationAl team reports remaining hopeful about their future.

Note: The appendix below provides a graphical timeline of the company's history.

\section{References}

Janz, B. (2014). After the big idea: Entrepreneurial success through high performance startup teams (https://eiexchange.com/content/22-after-the-big-idea-e ntrepreneurial-success-throu?search=after $\% 20$ the $\% 20$ big\%20idea\%20entrepreneurial\%20success\%20throug h\%20high\%20performance\%20start\%20up\%20teams) . Entrepreneurship \& Innovation Exchange.

Todorovic \& Moenter (2010). "Tenant Firm Progression within an Incubator: Progression toward and Optimal Point of Resource Utilization" (http://www.asaecenter.org/Resources/EUArticle.cfm?lt emNumber=11531) . Academy of Entrepreneurship Journal.

Diakanastasi, Karagiannaki, Pramatari (2018). "Entrepreneurial Team Dynamics and New Venture Creation Process: An Exploratory Study Within a Startup Incubator". SAGE Journals.

\section{Footnotes}

1 Kleibrink, M. (2004). "Diagnosis: Founderitis" (http://www.asaecenter.org/Resources/EUArticle.cfm?It emNumber=11531) . Executive Update. ASAE.

Additional Search Terms: egocentric leaders, toxic management, toxic leadership, poor communication, control freak 


\section{Appendix: Graphical Summary of the Team's Timeline}

The following graphic summarizes the company phases, significant team members added at each, the general management structure, the decision making approach, and the key challenges and risks.

\begin{tabular}{|c|c|c|c|c|}
\hline Phase & $\begin{array}{l}\text { Significant team } \\
\text { members }\end{array}$ & Structure & $\begin{array}{l}\text { Decision } \\
\text { making }\end{array}$ & Challenges and risks \\
\hline Founding & $\begin{array}{l}\text { Justin and Caleb, } \\
\text { transient members, } \\
\text { freelancers; } \\
\text { primarily part-time } \\
\text { commitment }\end{array}$ & $\begin{array}{l}\text { Non- } \\
\text { existent }\end{array}$ & Democratic & $\begin{array}{l}\text { Disorganization, lack of } \\
\text { product progress, } \\
\text { operational challenges }\end{array}$ \\
\hline $\begin{array}{l}\text { Phase } 1 \text { - } \\
\text { major } \\
\text { pivot }\end{array}$ & $\begin{array}{l}\text { Caleb as CEO, Justin } \\
\text { as CTO; technical } \\
\text { freelancers and } \\
\text { team members }\end{array}$ & Flat & $\begin{array}{l}\text { More } \\
\text { centralized } \\
\text { decision- } \\
\text { marking }\end{array}$ & $\begin{array}{l}\text { Going on instinct, invalid } \\
\text { market assumptions, lack } \\
\text { of product-market fit, no } \\
\text { clear direction, ownership } \\
\text { conflicts }\end{array}$ \\
\hline $\begin{array}{l}\text { Phase } 2 \text { - } \\
\text { new } \\
\text { market }\end{array}$ & $\begin{array}{l}\text { Significant } \\
\text { fluctuation; added } 5 \\
\text { including COO and } \\
\text { VP Marketing; }\end{array}$ & Hierarchical & Dictatorial & $\begin{array}{l}\text { Significant team turmoil, } \\
\text { technology skills, } \\
\text { assuming product-market } \\
\text { fit, communication styles }\end{array}$ \\
\hline $\begin{array}{l}\text { Phase } 3 \text { - } \\
\text { new } \\
\text { iteration }\end{array}$ & $\begin{array}{l}\text { Added Product } \\
\text { Manager }\end{array}$ & $\begin{array}{l}\text { Flatter, } \\
\text { more open }\end{array}$ & $\begin{array}{l}\text { Semi- } \\
\text { democratized }\end{array}$ & $\begin{array}{l}\text { Unstable product, new } \\
\text { team dynamics, continue } \\
\text { struggles with product- } \\
\text { market fit }\end{array}$ \\
\hline Current & $\begin{array}{l}\text { Added significantly } \\
\text { more technical } \\
\text { talent }\end{array}$ & $\begin{array}{l}\text { Flatter, } \\
\text { more open }\end{array}$ & Evolving & $\begin{array}{l}\text { Finding product-market } \\
\text { fit; sustaining operations } \\
\text { without running out of } \\
\text { cash }\end{array}$ \\
\hline
\end{tabular}


